\title{
Analysis on the Current Situation and Strategies for the Cultivation of Logistics Talents in Linyi
}

\author{
- Take the case of Linyi commodity city
}

\author{
Lei Wang \\ Linyi University, \\ Feixian, Shandong, China
}

\begin{abstract}
The development of logistics in Linyi needs advanced management experience. We should use the logistics management experiences of other major cities in China and of other countries for reference, and change the "enterprise logistics" into "logistics enterprise". All above reflects the reform of logistics management and operation system in Linyi. However, currently speaking, the logistics talents that has been cultivated cannot meet the demand, while the skilled and top logistics management talents with comprehensive quality is the fundamental part in accelerating the developments of modern logistics. Therefore, it is imperative for local government, especially the education, personnel and labor department to strengthen the cultivation of talents that are in great need in modern logistics industry.
\end{abstract}

Keywords-Cultivation of logistics talents, Modern logistics, Logistician

\section{INTRODUCTION}

Being the third largest commodity gathering and distributing center in china, Linyi has been given allocation of "The logistics of Linyi will go to anywhere in the world". The highways that radiates into all directions- it can be seen from the all-around local highway freight terminals, has indeed make great contributions to the local or non-local products' being transported in great quantity to other parts of the country, or even into the world quickly and efficiently. According to expectations of experts, for the next decades, 30000 to 40000 skilled and top logistics management talents will be in great need in our country [1]. Currently speaking, at the beginning of modern logistics, various problems will appear in logistics links, the logistics technology is laggard, the skilled and top logistics management talents are in shortage. According to some employers, employing a logistics director is much more difficult than hiring a general manager. With the manufacture of mechanical products, for example, during the production process, the processing time accounts for only $10 \%$ or so, while the rest, it means the $90 \%$ of time are spent on the logistics, this, resulted in staggering huge waste. To keep up with the world, we should take major efforts to invest resources into promoting the development of logistics industry. Traditional education system failed to provide much more fresh blood for the development of modern logistics, so, in order to meet the demand of modern enterprises for logistics management talents, it's imperative for us to accelerate the cultivation of logistics talents to better the performance of enterprises, further to make greater profits for enterprises themselves and the shippers.

\section{THE CURRENT SituATION FOR THE CULTIVATION OF LOGISTICS TALENTS IN LINYI}

The logistician qualified certificate training and internal training in enterprise are the two main kinds of logistics talents training in Linyi. The training and examinations of the logistician-qualified certificate are in the separate charge of the China Federation of Logistics and Purchasing and the Ministry of Human Resources and Social Security, the examinations is usually hold twice a year, on May and November annually.

China Logistics and Purchasing Federation of logistics staff is divided into three categories

The logisticians of the China Federation of Logistics and Purchasing is classified into three categories, namely assistant logistician, logistician and senior logistician. The logisticians of the Ministry of Human Resources and Social Security are classified into four categories, namely logistics personnel (equals to national professional qualification level 4), assistant logistician (national professional qualification level 3 ), logistician (national professional qualification level 2) and senior logistician (national professional qualification level 1). Linyi Logistician Training Center is the only training institutions that authorized by the China Federation of Logistics and Purchasing. The rests are all agent-training institutions of the Ministry of Human Resources and Social Security, like the Linyi University, Linyi Vocational Technology School, both will organize annual training and examinations in the charge of the Ministry of Human Resources and Social Security on assistant logistician and logistician.

However, the teaching methods and teaching means are too simple. First, the purpose of training is to meet a certain position of the professional and technical personnel education model, not to only focus on imparting knowledge and ignore the students' comprehensive ability of experiment. Second, the teaching conditions and teachers are too bad. What's more, 
the school system only see the needs of logistics personnel, ignoring the quality of talent requirements. Students only know the book knowledge, lacked in innovation in the process of practice. Last but not the least, the lack of understanding of some new teaching methods is a problem (these foreign successful simulation teaching mode, such as heuristic teaching, case teaching and discussion teaching are applied less).

Enterprise internal training usually take the model of "equipping freshman with skilled accountants", and focus on the process operations. Although some enterprises will employ professional logisticians to train the employees, however, the training content is usually rather simple and the frequency is low, in a word, it is not systematic.

Practical talents are too few. From the actual situation, most companies specializing in Logistics do warehousing and distribution transportation. These two aspects are the most important elements in the logistics activities of the two elements .Companies need more practical talents ,such as logistics talent forklift operator ,keeper and classification. Social training institutions training logistics branch is often a number of managers who are few specific forklift operations such as sorting and professional training in warehousing. At present, most talent of Linyi city are trained by the enterprise and promoted to other places. The actual demand is large, but the shortage of skilled talents is very serious.

\section{THE QUANTITY AND STRUCTURE OF LOGISTICS TALENTS IN LINYI}

As for logistics education, in Linyi, 200 or so undergraduates will graduate from the local university every year; 300-500 students complete their studies in junior colleges or high vocational schools. However, the undergraduates are from all over the world, few of them would choose to stay in Linyi after graduation. Although most of college students live in Shandong, for various reasons, finally they will leave Linyi as well. From this perspective, the quantity of logistics talents in Linyi is far from enough to meet the local demand, the logistics talents is in great shortage.

As for the cultivation of logisticians, the China Federation of Logistics and Purchasing focus mainly on students when training assistant logisticians and logisticians, and the number capped at 200 or so. Among them, most of assistant logisticians are college students, logisticians are mainly undergraduates. On one hand, because of the limited knowledge and training fee, there are only a limited number of trainees, while on the other hand, majority of students would look for jobs at other cities, only a small number of them are willing to remain in Linyi. Apart from students, social logistics employees also are eligible to attend the training course of the Ministry of Human Resources and Social Security, but, for various reasons, their motivation to attend the training courses is low, as well as the percentage of employees with certificates.

As for internal training in enterprise, although the invest of enterprise in training is huge, it focus mainly on general management training, while neglect the professional training on logistics. The internal training of enterprise on logistics based mainly on operations and security training. Currently speaking, few enterprises would voluntarily contact related logistics colleges for training course, this, also reflects the weakness of human resource management in enterprises [2].

High-level logistics talents are too few. Only a high level of logistics professionals can hold the modern Linyi. Because of rapid development of flow industry, enterprises generally feel that, logistics management talents that are able to deploy a high level of scientific with the logistics management experience and understanding of modern logistics information management in Linyi is difficult to recruit.

\section{STRATEGIES FOR THE CULTIVATION OF LOGISTICS TALENTS IN LINYI}

Related government management department should actively propel to enlarge the training scale and numbers of logistics talents in colleges and universities.

The government should support the cooperation between transport \& logistics enterprises and colleges \& universities strongly, and then the scientific advantages of colleges and universities can guide the practices and tests of enterprises, in this way the theory can combine with the practice [3]. A large number of talents ---with can-do spirit, and are familiar with the operation of law in logistics---can be cultivated rapidly when the teaching advantages of schools is taken to propel the training of professional and technical personnel and management talents.

The Government should permit and encourage the university to open up modern logistics majors, set modern logistics course that are based on market, and list major of logistics into discipline catalogue set by State Education Committee of China. The Government should direct help available enterprises, non-governmental organizations and industry associations to run schools jointly with colleges and universities, so as to train employees technically, and provide logistics talents that are in great need in modern logistics industry.

Increase training efforts on employees, and encourage all employees to attend short-term in-service training.

The employees mainly trained on basic logistics knowledge, credit awareness, business skills, laws, and regulations, and they are only qualified to get employment when they have attended the professional training and got the certificate, and a database of employees should be established [4]. Through promoting the overall quality of the employees across the industry, solid foundation of talents lay for the scientific and harmonious development of transportation and logistics industry. Besides, we should explore various ways to cultivate and attract logistics talents, learn from developed countries, and appropriate special funds in a given period to train and discipline logistics personnel, to build up the lifelong education system of employees. 
Based on professional and practical training of logistics personnel, we should carry out certified qualification system among logistics employees, and improve the quality of logistics management and technology professionals continuously.

Colleges and universities should strengthen the cultivation of logistics talents.

Logistics vocational education should adhere to the ideological awareness of modern logistics, combined with the specific requirements, the orientation of Higher Vocational Education and the combination of knowledge and ability. Pay attention to the students' autonomous learning ability, including the ability of interpersonal communication, social adaptation, psychological endurance and other abilities that train and cultivate students' comprehensive quality. Therefore, the logistics management curriculum and teaching content will focus on these ideas and make adjustments.

The purpose of higher vocational education is to train high-quality logistics personnel; the teaching content of logistics operation should close to the actual business, so that students master the practical knowledge and skills theory to solve the conflict of logistics management professional learning and enterprise actual problems. First, the reform of teaching mode is a way to improve the personnel practice and achieve the depth of school-cooperation mode. Second, the course should show his positioning characteristics, education and national. In addition, improve the vocational qualification certificate system. Last but not the least, Logistics Vocational Education is a modern means of teaching which focuses on cultivating students' practical ability should use modern teaching means in order to enhance its visibility and operability and practicability.

Regular seminars focused on logistics and training should hold for logistics management, and attention should pay to study the new circumstances, and solve new problems. Besides, we must update the management idea, improve execution ability and efficiency on management, cultivate a studied style team that consists of logistics management with firm politics, clear cognition and competent professions, and lay solid foundations for the scientific and harmonious development of transportation and logistics industry.

Encourage and guide scholars in universities, market research firm, and organs of government and enterprise personnel to develop theoretical and practical research on modern logistics.

Especially to actively guide the cooperation between logistics enterprises and research consultancy or colleges and universities in capitals and techniques, speed up the training of high-grade logistics management talents and technical talents that are familiar with logistics business and have integration abilities of span-subject[5].

Make policy to encourage related departments and enterprises to introduce high-grade logistics management talents and technical talents from abroad.
This is an effective way to promote the overall quality of logistics talents and accelerate the development of modern logistics industry of our country the way which local government of various levels should guide logistics enterprises to abide by with the more rapid development of economic globalization. Government and enterprises should create an atmosphere of cultivating, valuing and inspiring talents through introducing and reserving talents. In modern economic conditions, the availability of well-qualified talents determines the logistics level. Based on introducing, training and disciplining talents, the related government administrative departments should introduce advanced logistics management concepts, use a combination of management methods, which concluding the logistics operation, capital operation and market operation, to enhance the level of logistics management.

\section{V.SUMMARY}

After all, the competition of logistics is the competition of talents. There is no talent, there is no development of the power and innovation. If we compare the market to sea, then logistics providers are the warships that will rely on and control the market. The building of the warships demands for modern techniques and equipments, adequate funding and powerful hardware platform; the sailing of the warships need well-qualified captain and crew, only combining the above, can the enterprise warship make success in the sea of market. Logistics can live without management; management brings about both economic and social benefits. The experiences of developed countries proved that the key to develop the third party logistics, to realize logistics integration is equipping ourselves with an excellent team on logistics management. The gap between developed countries and us are not only the gap in equipment, technology and capital, more than all above, it is the gap in concepts and knowledge [6]. Only when logistics employees and managers improve their own quality continuously, keep studying and applying advanced technology and methods, can the logistics market of our city be enlarged and much stronger, to lay solid foundations for the building of a worthy "capital of logistics".

\section{REFERENCES}

[1] Ji Jing, Analysis on Current Situation and Strategies for the Cultivation of Logistics Talents of China [J]. Logistics Technology, 2005,(5).

[2] Lan Peiwu, Cao Cuizhen, Brief Analysis on Education and Cultivation of Modern Logistics Talents [J]. Journal of Shanxi University of Finance and Economics, 2005, (3).

[3] Zhang Futong, Brief Analysis on Cultivation of Logistics Talents in Enterprise $[\mathrm{J}]$. Journal of Tianjin Institute of Financial and Commercial Management, 2005, (3).

[4] Zhao jing, Brief Analysis on Problems Existing in Modern Logistics Industry and Strategies for it [J]. Logistics Management, 2007,(2):pp.38-44.

[5] Sun Jianhua, Development Strategy Study of Small and Medium-sized Logistics Enterprises [J].Legal System and Society, 2007,(6):pp.348-349.

[6] Mo Boyu, The Superiority, Problems and Strategies of Private Logistics Enterprise [J]. Logistics SCI-TECH, 2007, (4):pp.4- 7. 